\section{A NOTE ON A CASE OF FIBROMA OF THE SMALL OMENTUM.}

BY J. JACKSON CLARKE, M.B. LOND., F.R.O.S. ENG., AESISTANT SURGEON AT THE NORTH-WHST LONDON HOSPITAI ATD AT THE CITY OF LONDON ORTHOP EDIO HOSPITAI.

IN the Transactions of the Royal Medical and Chirurgical Society for the year 1900, Mr. Pearce Gould has recorded a case that is not only remarkable in itself but also lends a reflected interest to a case that I communicated to the Pathological Society of London in the year 1892. Since

FIG. 1.

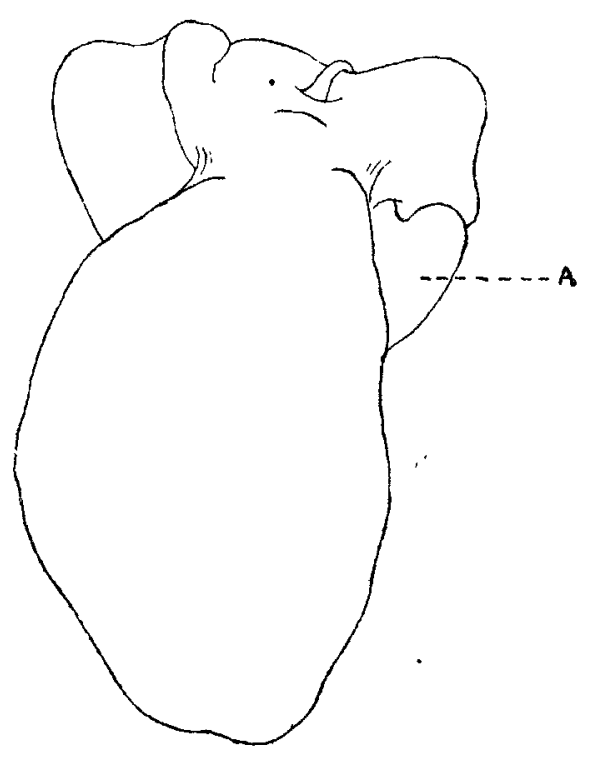

The tumour and the liver and the cardiac end of the stomach (A seen from the front.

Mr. Pearce Gould, in the record of his case of sarcoma of the gastro-hepatic omentum, has fully quoted the pathological account of my specimen as well as the comments that I made upon the surgical anatomy of the tumour, the only reason

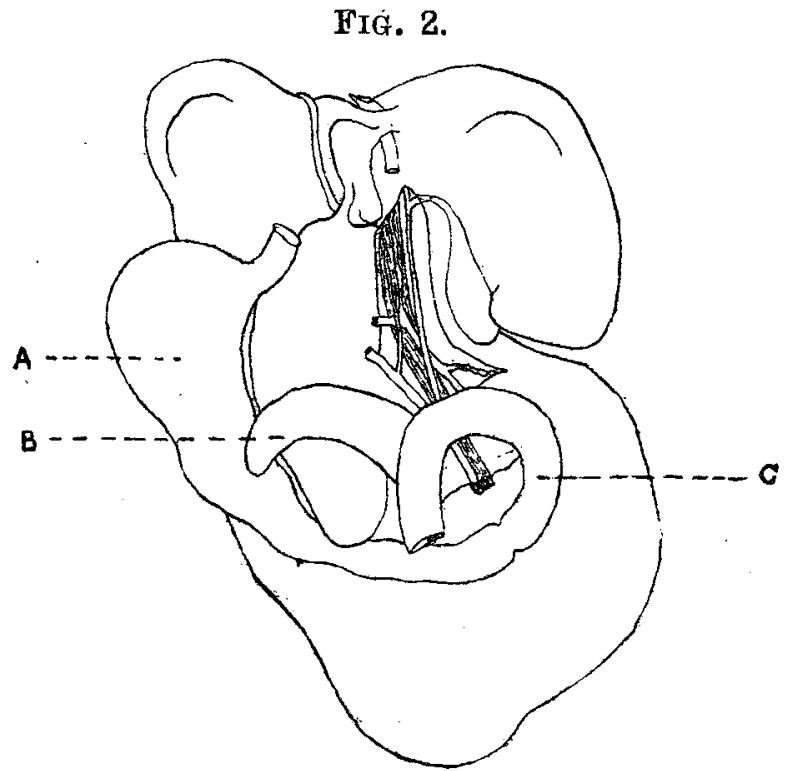

The liver, the stomach and duodenum, the pancreas, and the tumour seen from behind. The structuı es in the right bordin of the small omentur haver secting away the posterior layer of perit
stomach $; \mathbf{B}=$ pancress ; $\mathbf{C}=$ duodenum.

that I have for bringing the subject forward again is that I may remove a defect from the record of my case as it now stands in the place above referred to. Mr. Pearce Gould has drawn attention to this defect by expressing regret that in $\mathrm{my}$ account no details of the alteration in the position and shape of the stomach and duodenum or any exact account of the state of the portal ressels and common bile-duct are given. It is fitting to state that these details were included in sketches that $I$ exhibited with the tumour before the Pathological Society of
London. With these sketches before me I can now state that the stomach was of an elongated and narrowed form, the greater part of it lying obliquely behind the tumour. This elongation of the stomach resulted in the pylorus being at a much greater distance from the cardiac orifice than is normally the case. The pylorus lay behind the growth, a little to the right of its median line and about the junction of its lower and middle thirds. From the pylorus the duodenum passed first upwards, then to the left, and finally downwards, completing three-fourths of a circle. The opening of the common bile-duct into the duodenum was situated vertically above the pylorus in the middle of the horizontal portion. The common bile-duct, the hepatic artery, and the portal vein were elongated and lay behind the npper half of the tumour near its right border. The main arterial supply of the growth was an offshoot of the gastro-duodenal branch of the hepatic artery. There was a hepatic branch of the superior mesenteric artery which ran up behind the portal vein to the liver.

Portland-place, $W$.

\section{A eftirror}

\author{
oF
}

\section{HOSPITAL PRACTICE, BRITISH AN D FOREIGN.}

Nulla autem est alia pro certo noscendi via, nisi quamplurimas morborum et dissectionum historias, tum aliorum tum proprias collectas habere et inter se comparare-MoRgaGNI De Sed et Caue corb. lib. iv Procemilum.

\section{WESTMINSTER HOSPITAL.}

A CASE OF PY 开MIA AFTER ABORTION IN WHICH THF PERICARDIUM AND THE LEFT PLEURA WERE OPENED AND DRAINED; DEATH.

(Under the care of Dr. W. A. WILLS and Mr. W. G. SPENCER.)

DRAINAGE of the pericardial cavity is still an extremely rare operation, though several of those that have been described have been very successfal. It is now generally recognised that it is very difficult to aspirate the pericardinm on account of the tendency manifested by the heart to float towards the sternum when the patient is in the recumbent posture. The following case illustrates the importance of ascertaining the nature of the micro-organism present in a case of septicæmia or pyæmia, for we have no reason to think that anti-streptococcic serum would be of any avail in infection due to a staphylococcus. For the notes of the case we are indebted to $\mathrm{Mr}$. $\mathrm{H}$. Hallilay, house physician.

A married woman, aged 24 years, with six children, was admitted into Westminster Hospital on April 4th, 1901, under the care of Dr. de Havilland Hall and during his absence came under the charge of Dr. Wills. The patient was in her usual health until a fortnight before admission. She then was attacked by malaise, joint pains, and fererishness, and took to her bed at once. She was three months pregnant and at the end of the first week of her illness she had a miscarriage. She had had no vaginal discharge before, but after the miscarriage a discharge came on and lasted for about a fortnight. She was admitted as suffering from acute rheumatism with pericarditis.

She was a stout, somewhat florid woman. Her temperature was $103^{\circ} \mathrm{F}$. There was considerable dyspncea. Her face was livid and the alæ nasi were working. She was sweating freely but there were no joint pains. There were evident signs of pericardial effusion, the pracordial dulness extending to the left just bey ond the nipple line and upwards to the upper border of the third costal cartilage. The impulse was feeble and diffuse. There was a distinct pericardial rub heard at the left margin of the sternum over the base of the heart and the heart sounds were muffled but clear. From the angle of the scapula to the base of the left lung there were dulness, whiffy tubular breathing, and bronchophony, with some increase of vocal fremitus, pointing to pneumonic consolidation of the left lower lobe. Elsewhere over the lungs there were no abnormal physical signs. The pericardial effusion did not 